ACTA MYCOLOGICA

Vol. 42 (2): 187-191

2007
Dedicated to Professor Alina Skirgietto

on the occasion of her ninety-fifth birthday

\title{
Clitocybe splendoides H.E. Bigelow (Agaricales, Tricholomataceae), a new species for Poland
}

\author{
HALINA KOMOROWSKA
}

Department of Mycology, W. Szafer Institute of Botany, Polish Academy of Sciences

Lubicz 46, PL-31-512 Kraków

Ko morowsk a H. Clitocybe splendoides H.E. Bigelow (Agaricales, Tricholomataceae), a new species for Poland. Acta Mycol. 42 (2):187-191, 2007.

Records of Clitocybe splendoides H. E. Bigelow, a rare fungus belonging to the species group of the $C$. gibba type, associated with deciduous forests, especially beech forests, collected at three localities in Poland are described.

Key words: Agaricales, Tricholomataceae, Clitocybe splendens, C. splendoides, Poland

\section{INTRODUCTION}

Clitocybe splendoides H.E. Bigelow, Lloydia 31: 49. 1968. - C. splendens (Fr.) Gillet ss. Bresadola, Icon. Mycol. IV: 168. 1928. - C. infundibuliformis (Fr.) ex Schaef. var. splendens (Bres. nec al.) Kühner \& Romagnesi Flore Analytique: 138. 1953.

Systematic ARRANGEMENT: Bige low (1968)decided to propose the epithet splendoides as nomen novum for C. splendens (Fr.) Gillet ss. Bresadola, Icon. Mycol. 4: pl. 168. 1928 because "in the sense of most modern investigators, $C$. splendens is a synonym of $C$. gilva, $C$. inversa, or $C$. flaccida. While there are some disagreements in the literature on the limits of these three species, at least all have ornamented spores" (Bigelow 1968: 49). These three species are now placed in the genus Lepista, and L. splendens (Pers.) Gillet is either distinguished as a separate species (Bon 1997) or considered as a synonym of L. gilva or L. flaccida (Kuyper 1995; Hor a k 2005).

C. splendens sensu Bresadola has smooth, eliptical, obovate or pyriform spores in face view, and occurs on leaves under beech, trees; its nomen novum $=C$. splendoides H.E. Bigelow. Although Bigelow initially placed it in the section Infundibuliformes because of the shape of the pileus and the resemblance of the pileal colour to some colours occasionally found in C. gibba (Fr.) P. Kumm. (Bigelow 1968: 43), he later recognised this disposition as incorrect. Species close to $C$. gilva have encrusted pigments on the surface hyphae, and since such pigments are absent in $C$. splendoides, he placed it in the section Candicantes, noticing that $C$. splendoides $\mathrm{H}$. E. Bigelow and C. catina (Fr.) Quél. may represent a possible link of the Candicantes to 
the Infundibuliformes (Bige low 1982: 119). Other mycologists assign it to the new section Gilvoideae Harmaja (Singer 1978: 209, 210; Clém en çon 1984: 38). Bon (1997: 38) and Hor ak (2005: 106, 108), for instance, place it in the section Clitocybe ( = Infundibuliformes $\mathrm{Fr}$.) with other species of the group C. gibba.

Selected Descriptions: Bigelow, Beihefte Nova Hedw. 72: 119. 1982; Bon, Doc. Mycol. 13(51): 14. 1983; Clémençon, Beihefte Z. Mycol. 5: 38. 1984; Schwöbel, Beiträge Kenn. Pilze Mitteleuropas 1: 7. 1984; Bon, Doc. Mycol. Mémoire 4: 38. 1997; Urbonas, Lietuvos grybai 8/2: 33. 1997.

ICONOGRAPHY: Bresadola 1928: 168; Bon 1997: pl. 1A; Schwöbel 1984: 7, Abb. 1 (as C. splendens ss. Bresadola); Urbonas 1997: VI. 4e-h.

Many new rare and interesting species, including Clitocybe splendoides, were found during investigations on the genus Clitocybe.

\section{MORPHOLOGICAL CHARACTERISTICS}

Pileus 3-8 cm, plane, soon depressed, at last infundibuliform, margin straight or narrowly decurved, not striate, yellowish, oldest specimens beige-white, surface moist, context thin, whitish, odour present but undefined. Lamellae forked, intervenose, thin, narrow, up to $5 \mathrm{~mm}$, crowded, white edges even and straight, somewhat undulate in age. Stipe 3-6 cm long, apex $0.5-1.0 \mathrm{~cm}$ broad, straight, cylindrical, whitish, surface glabrous, base with whitish tomentum.

Dry specimens with sunset pileus, 10D4 to 10D6, 10E6, and whitish stipe, 10B1, 10B2 (Maerz, Paul 1950), lamellae seem slightly duller than stipe because of water-brown edges. In exsiccates pileus not staining deep chestnut brown or dark chocolate brown where treated with $5 \% \mathrm{KOH}$ (see first specimens in colour illustration, Fig. 1).

Hyphae of pileus cutis cylindric, 4.6-6.1 $\mu \mathrm{m}$, of context 7.7-13.8 $\mu \mathrm{m}$ diam, hyaline in $\mathrm{KOH}$, membranal and intracelular pigments present. Cystidia absent. Basidia 20.4-28.1 × 4.1-6.1 um, 4- spored rarely 1 or 2-spored. Spores 6.1-7.7 (8.2) $\times(2.8-)$ 3.1-4.3 $\mu \mathrm{m}$, elipsoid to obovoid or pyriform, not amyloid (Fig. 2).

Rare in deciduous or mixed forest, on beech leaves. August to October.

Examined sPecimens: 343. Lvov Upland, 343.2. The Roztocze, „Debry” reserve, near Krasnobród, 5.08.2004, leg. H. Komorowska, KRAM-F 55578; 512. Northern Subcarpathian Region, 512.3. Brama Krakowska Gate, Kraków, Las Wolski Forest, 29.10.2004, leg. J. Lichoń, KRAM-F 55580; 522. Outer Eastern Carpathians, 522.1. Beskidy Wschodnie Mts., 522.12. Bieszczady Zachodnie Mts., S. Myczkowski, „Hulskie” reserve, Tilio-Carpinetum, 20.09.1996, leg. H. Komorowska, KRAM-F 55579.

Numbers and names of geographical regions follow Kondracki (2001).

\section{NOTES}

C. splendoides is reported in the literature only by specialists working on the genus Clitocybe and is usually not distinguished from the very common $C$. gibba by other mycologists. Only a very detailed examination of specimens under a microscope reveals that there exists a group of similar species $(C$. splendoides H.E. Bigelow, $C$. glarosa Reling \& Monthoux, C. costata Küner \& Romagn., C. bresadoliana Singer and $C$. gracilis (H.E. Bigelow \& A.H. Sm.) Harmaja or $C$. alnicola H.E. Bigelow) 


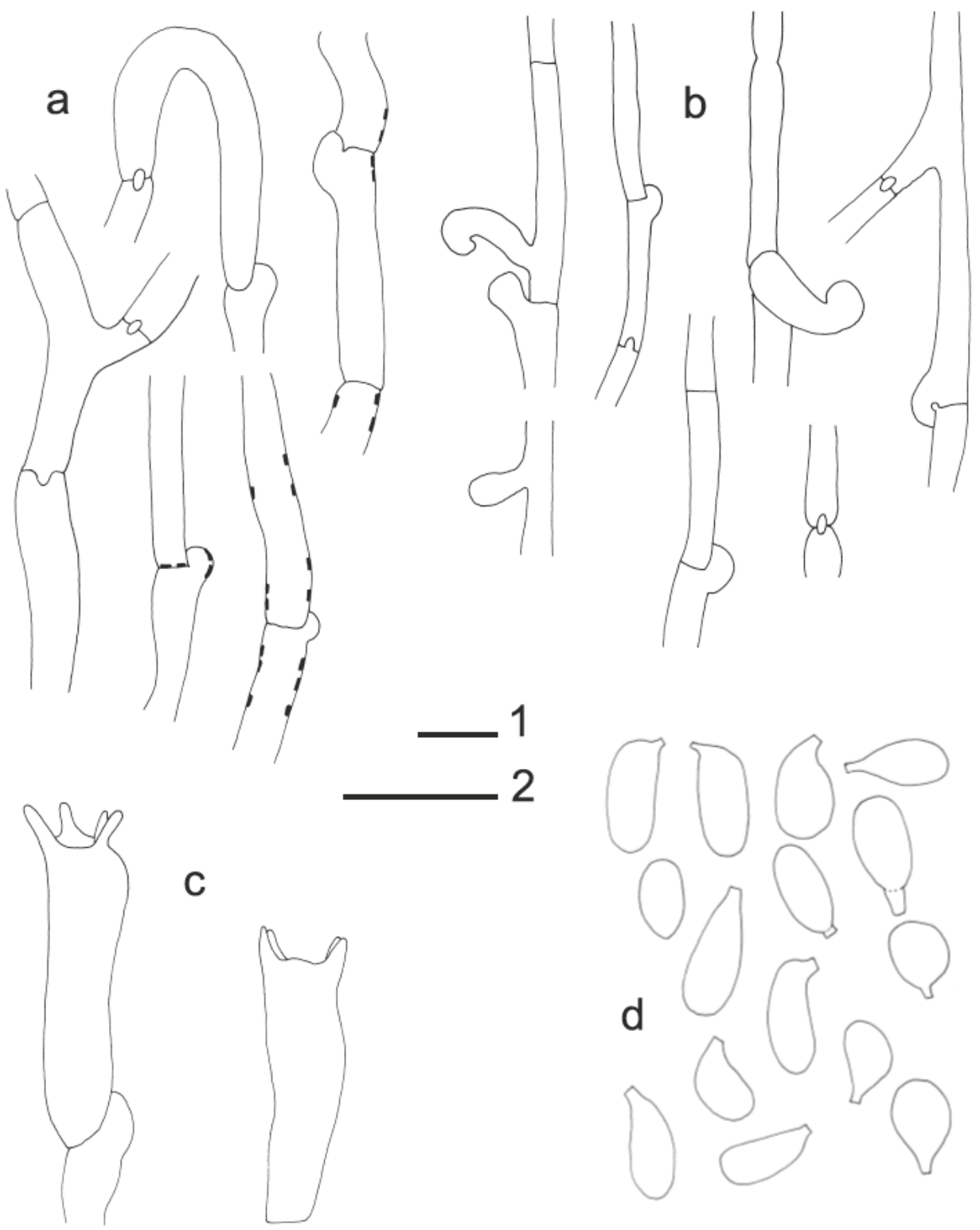

Fig. 2. Microscopic elements of $C$. splendoides (KRAM F 55578): a - hyphae of pileipellis, $\mathrm{b}$ - hyphae of stipitipellis, $\mathrm{c}$ - basidia, $\mathrm{d}$-spores; 1 - scale bar $=10 \mu$, for a and b, 2 - scale bar $=10 \mu$, for $\mathrm{c}$ and $\mathrm{d}$.

differing in the spore size and shape as well as the macrochemical reaction of the pileipellis with $5 \% \mathrm{KOH}$. However, as this reaction may not always be identical even on the same specimen (e.g. margin, pileal centre) and depends on a variety of factors (Harmaja 1969: 30), it may not be considered as a good diagnostic character differentiating the species. 
It was very difficult to find any information on the distribution of $C$. splendoides in Europe in the available literature. Some data on the occurrence of this species were obtained in Luxemburg (An onym ous 1990: (81), Lithuania (Urbonas et al. 1986: 18; Urbonas 1997: 33) and Germany (Schwöbel 1984: 7). There are also reports on collections from Europe (without details, however) and the USA (Bigelow 1968, 1982; Bon 1997; Horak 2005). Bresadola (1928) also reports this species from Asia (Siberia) and South Africa.

The anatomy of the pileus is very uniform in the genus Clitocybe, therefore, as suggested by Harmaja (1969: 25), only a detailed examination of the epidermis and subepidermis can help identify the species. The most reliable features are the shape and size of spores, the two being the most constant characters. Bigelow emphasized the lack of incrustation of pileipellis hyphae in $C$. spendoides, a feature that is present in $C$. gibba and other species of its complex. In my opinion this feature is of lesser importance and the observations of the Polish specimens lead me to believe that the shape and size of spores is the most significant character that distinguishes C. splendoides from closely related species. Spores are mostly elongated, narrowly elliptical or elliptical, and very few are lacrimoid, similar to those of C.gibba but smaller.

Species belonging to the $C$. gibba complex will be described in a separate publication where the differences between them will be discussed in detail.

Acknowledgements. The author wishes to thank Dr. Anna Ronikier for the English translation of a part of this paper and Mr Jacek Lichon for donating the specimen from Kraków. The studies, supported by the State Committee for Scientific Research (KBN grant PO4G 024 22), were carried out in reserves and national parks in Poland in the period between 2002 and 2004.

\section{REFERENCES}

An onym ous 1990. Rapport sur la session de la SMF tenue à Echteenach (Grand-Duché de Luxembourg) du 28 september au 4 octobre 1989. Bull. Soc. Mycol. Fr. 106: 60-87.

Bresadola J. 1928. Iconographia mycologica, vol. 4, Societá Botanica Italiana, Mediolani.

Bige low H. E. 1968. The Genus Clitocybe in North America. II. Section Infundibuliformes. Lloydia 31(1): 43-62.

Bon M. 1997. Les Clitocybes, Omphales et ressemblants. Tricholomataceae (2), Clitocyboideae. Doc. Mycol. Mémoire Hors 4: 1-181.

Clémen nçon H. 1984. Kompendium der Blätterpilze: Clitocybe. Beih. Z. Mykol. 5: 1-68.

Horak E. 2005. Röhrlinge und Blätterpilze in Europa. Kleine Kryptogamenflora IIb/2. Spectrum Academischer Verlag.

Kondracki J. 2001. Geografia regionalna Polski (Regional geography of Poland). Ed. 2. Wydawnictwo Naukowe PWN, Warszawa. 441 pp.

Kuyper T. W. 1995. Clitocybe (Fr.) Staude, Schwämme Mitteldeutschl.: XXVIII, 122. 1857 (In:) C. Bas, Th. W. Kuyper, M. E. Noordeloos, E. C. Vellinga (eds). Flora Agaricina Neerlandica. 3. A. A. Balkema/Rotterdam/ Brookfield: 42-62.

Maerz A, Paul M. Re a 1950. A dictionary of color. Ed. 2. McGraw-Hill Book Company, INC. New York, Toronto, London.

Schwö bel H. 1984. Trichterlinge aus dem C. gibba - Formenkreis (zur Abgrenzung von C. costata, C. catinus und C. splendens ss. Bres.). Beiträge zur Kenntnis der Pilze Mitteleuropas I: 5-10.

Singe r R. 1978. Keys for the identification of the species of Agaricales II. Sydowia 31: 193-237.

Urbonas V. 1997. Tricholomatales 2. (In:) V. Urbonas (ed.). Mycota Lithuaniae 8/2, UAB "Valstiečiu Laikraštis", Vilnius. 216 pp.

Urbonas V., Kala mees K., Lukin V. 1986. Conspectus florum agaricalium fungorum(Agaricales s. 1.) Lithuaniae, Latviae et Estoniae. Vilnius. 137 pp. 
Clitocybe splendoides H.E. Bigelow (Agaricales, Tricholomataceae), nowy gatunek dla Polski

\section{Streszczenie}

W czasie badań nad rodzajem Clitocybe, prowadzonych w rezerwatach i parkach narodowych w latach 2002-2004 w ramach projektu badawczego KBN (grant PO4G 024), zebrano wiele nowych, rzadkich i interesujących gatunków. Jednym z nich jest przedstawiony wyżej Clitocybe splendoides. Bigelow nadał tę nazwę znanemu z Europy i stwierdzonemu w USA C. splendens sensu Bresadola. Uzasadniał to dużym zamieszaniem w literaturze europejskiej i traktowaniem tego taksonu przez różnych mikologów jako synonimu $C$. gilva, C. inversa lub C. flaccida - gatunków z szorstkimi zarodnikami. Wszystkie te trzy gatunki obecnie większość mikologów umieszcza w rodzaju Lepista. Ich ranga taksonomiczna też jest różna - są dobrymi gatunkami lub tylko synonimami. $C$. splendens sensu Bresadola ma gładkie eliptyczne zarodniki, a jego nową nazwą jest od 1968 roku C. splendoides. Jego pozycja w rodzaju Clitocybe zmieniała się, był umieszczany w różnych sekcjach. Jest gatunkiem rzadkim i odnotowywanym głównie przez specjalistów, bywa nie odróżniany od $C$. gibba, który jako dość pospolity nie jest szczegółowo badany. Uchodzi uwadze zróżnicowanie zarodników (ich wielkość i kształt), a to one decydują o przynależności do danego taksonu, wraz z innymi cechami makroskopowymi czy choćby reakcją makrochemiczną skórki kapelusza traktowanej 5\% $\mathrm{KOH}$.

Inne gatunki z kompleksu $C$. gibba zostaną przedstawione w odrębnej publikacji. 

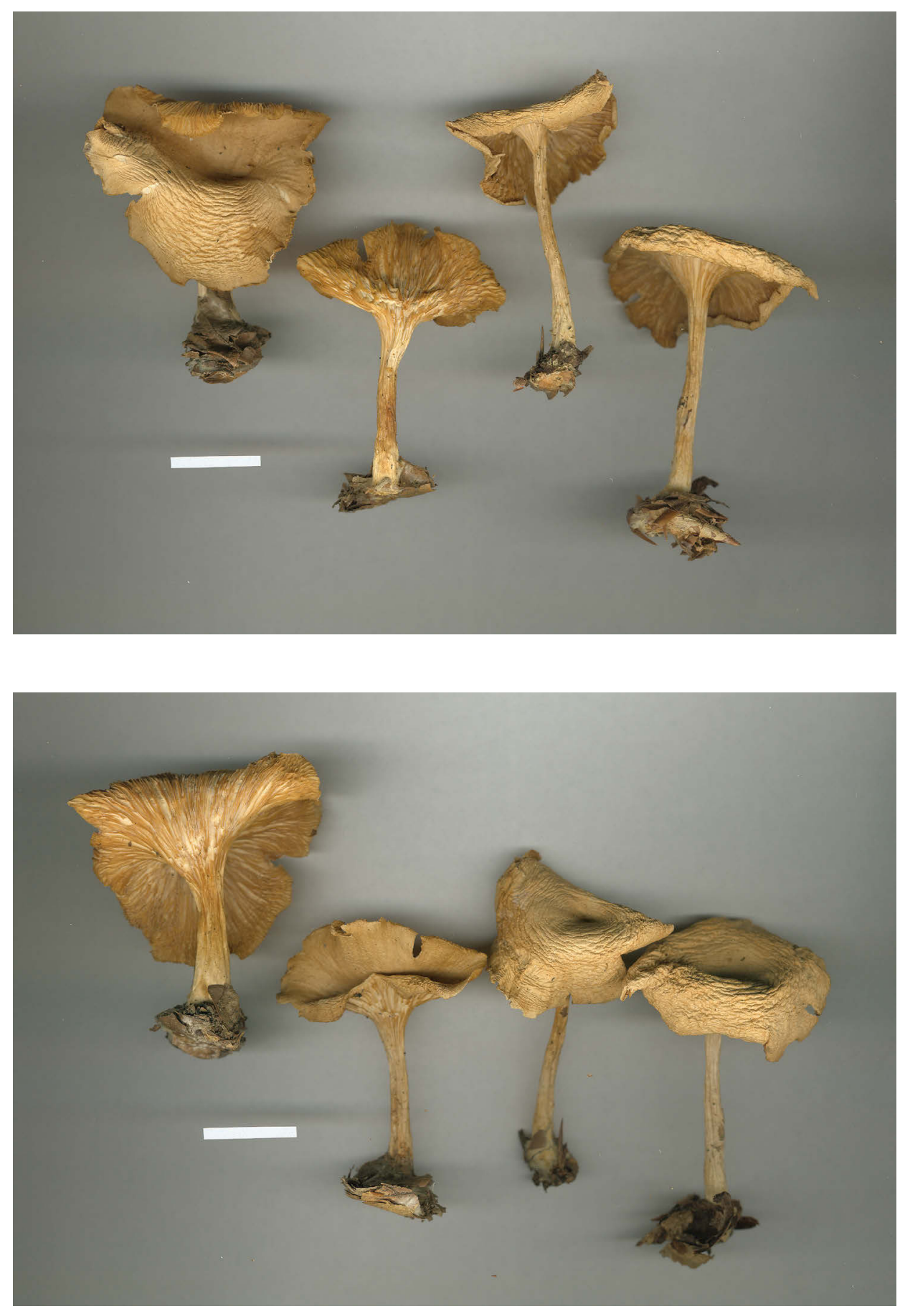

Fig. 1. Dry specimens of $C$. splendoides (KRAM F 55578). Scale bar $=2 \mathrm{~cm}$. No reaction of the pileipellis with $5 \% \mathrm{KOH}$ (see top photograph, left specimen). 